UDC 544.723

\author{
Y.D. Rublova, N.V. Amirulloeva, V.S. Protsenko, F.I. Danilov
}

\title{
SURFACE ACTIVITY OF SODIUM DODECYLSULFATE AT THE INTERFACE «SOLUTION BASED ON A DEEP EUTECTIC SOLVENT/AIR»
}

\author{
Ukrainian State University of Chemical Technology, Dnipro, Ukraine
}

\begin{abstract}
Surface activity of sodium dodecylsulfate and micelle formation in solutions based on deep eutectic solvents ethaline and reline (eutectic mixtures of choline chloride with ethylene glycol and urea, respectively) were investigated. The isotherms of surface tension were treated using Langmuir model and the adsorption parameters at the interface «solution/ air» were determined. The change in the nature of a solvent results in a decrease in the adsorption equilibrium constant in the following sequence: water $>$ reline $>$ ethaline $>$ ethylene glycol, which is caused by the corresponding changes in the solvents polarity and intensity of hydrophobic interactions. The critical micelle concentration of sodium dodecylsulfate is equal to $3.55 \cdot 10^{-3} \mathrm{M}$ and $2.14 \cdot 10^{-3} \mathrm{M}$ in solutions based on ethaline and reline, respectively. These values are lower than that in an aqueous medium $\left(8.11 \cdot 10^{-3} \mathrm{M}\right)$. An increase in the content of water additive in deep eutectic solvents has only a marginal impact on the adsorption equilibrium constant, but leads to an increase in the critical micelle concentration.
\end{abstract}

Keywords: adsorption, surface tension, deep eutectic solvent, sodium dodecylsulfate, effect of water.

DOI: $10.32434 / 0321-4095-2019-127-6-184-189$

\section{Introduction}

Nowadays, deep eutectic solvents (DESs) are considered as a new and promising type of ionic liquids. Different aspects of their synthesis, properties and applications attract considerable attention [1$3]$. Relatively high conductivity, non-fluidity, easy accessibility, environmental safety and low cost are the main advantages of DESs. It is important that the properties of DESs can be flexibly adjusted by the addition of some water to them [4-13].

Various physicochemical properties of DESs and the effects of water addition has been previously reported in detail $[1,4]$. However, a number of aspects of physicochemical characteristics are poorly investigated; for instance, the surface activity in DESbased solutions and the impact of water addition on the surface tension of DESs are practically unexplored. Only few papers touch upon this issue. Thus, Arnold et al. [14] investigated the surface activity of sodium dodecylsulfate (SDS), a common anionic surfactant, in a eutectic mixture of choline chloride and urea. However, this work was mainly focused on the processes of micelle formation and the parameters of adsorption at the air/solution interface were not determined. In addition, the establishment of the effects of the nature of different DESs and the content of water additive in them on the adsorption characteristics of dodecylsulfate anion is of great interest.

This work was aimed at studying the effects of the nature of a deep eutectic solvent and the content of water in it on the adsorption parameters at the interface «air/SDS solution» and the critical micelle concentration (CMC).

\section{Experimental}

Two deep eutectic solvents, ethaline and reline, were investigated in this work. They are eutectic mixtures of choline chloride with ethylene glycol and urea, respectively [1]. Ethylene glycol, urea and choline chloride (99\%, Acros Organics) were used as received. Ethaline and reline were prepared by mixing choline chloride $(\mathrm{ChCl})$ with ethylene glycol (EG) and urea, respectively, in a molar ratio of 1:2 at the temperature of $75^{\circ} \mathrm{C}$ until a homogeneous colorless liquid was formed. The prepared liquid mixtures were dried in vacuum $\left(75^{\circ} \mathrm{C}\right)$ by means of a drying cell Vacuum drier SPT-200. The drying of DESs was performed to achieve a constant content of hygroscopic water (not more than $1 \mathrm{wt} . \%$ ). The water content in DESs was evaluated according to 
the Fischer method.

In some experiments, a specified amount of twice-distilled water was added to the DES. A weighed sample of SDS was added to the DES to get $0.01 \mathrm{M}$ solution. This solution was further diluted to prepare those with a required content of SDS.

Surface tension was measured by the Wilhelmy plate method. Vibra HT-120 digital analytical balance (Shinko Denshi, Japan) was used to measure the force acting on the plate due to wetting. Before every measurement, the rectangular platinum Wilhelmy plate was annealed to achieve a contact angle of $\sim 0^{0}$. All measurements of surface tension were conducted 3-4 times and the average was taken. The expanded uncertainty in measurements of surface tension was $\pm 0.1 \mathrm{mN} \mathrm{m}^{-1}$. The temperature $(298.00 \pm 0.01 \mathrm{~K})$ was maintained by using a thermostat Flüssigkeitsthermostate Baureihe U/UH8 (Germany).

\section{Results and discussion}

Figure 1 shows that the surface tension of ethaline and reline abruptly decreases after adding SDS to the liquid. After reaching some content of SDS, the surface tension becomes invariable. It means that SDS shows a surface activity in DESbased systems and forms micelles in solutions. These data are in good agreement with the results of study [14], where the formation of cylindrical micelles in reline solutions was detected, whereas the spherical micelles were typical of water solution.

The addition of water to the DESs has no noticeable effect on the character of the isotherms of surface tension (Fig. 2), although influences the surface activity of SDS and the values of critical concentration of micelle formation. To determine $\mathrm{CMC}$, the graphs were plotted in the coordinates «change of surface tension (as compared with surface

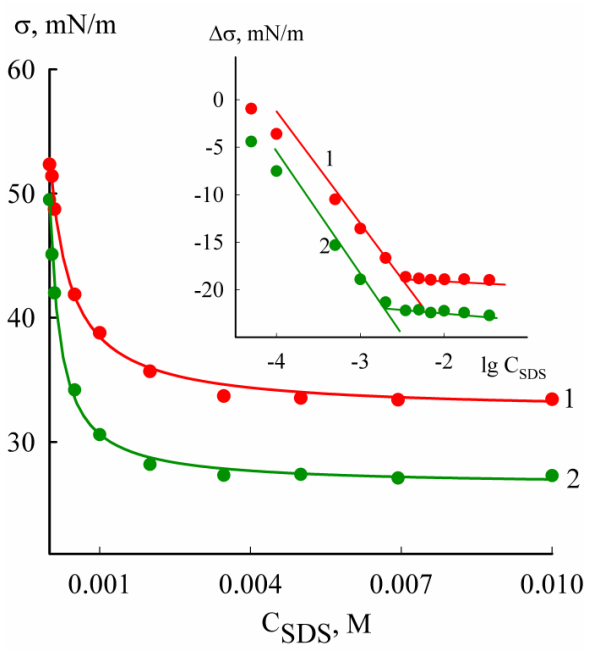

Fig. 1. Dependences of surface tension of solutions based on ethaline (1) and reline (2) on the concentration of SDS. The inset shows the dependence plotted in the coordinates «change of surface tension vs. logarithm of the content of SDS»

tension of pure solvent) vs. logarithm of the concentration of a surfactant». The found values of CMC are shown in Table 1.

The determined critical micelle concentrations of sodium dodecylsulfate are equal to $3.55 \cdot 10^{-3} \mathrm{M}$ and $2.14 \cdot 10^{-3} \mathrm{M}$ for the solutions based on ethaline and reline, respectively. The value for reline is practically coincides with that given in a previous study: $2 \cdot 10^{-3} \mathrm{M}[14]$.

It can be seen that the value of CMC of sodium dodecylsulfate in different solvents increases in the following sequence: ethylene glycol $<$ ethaline $<$ reline $<$ $<$ water. From the point of view of thermodynamic approach, a higher critical concentration of micelle formation means a higher affinity of a surface-active anion to the solvent. In this context, the established

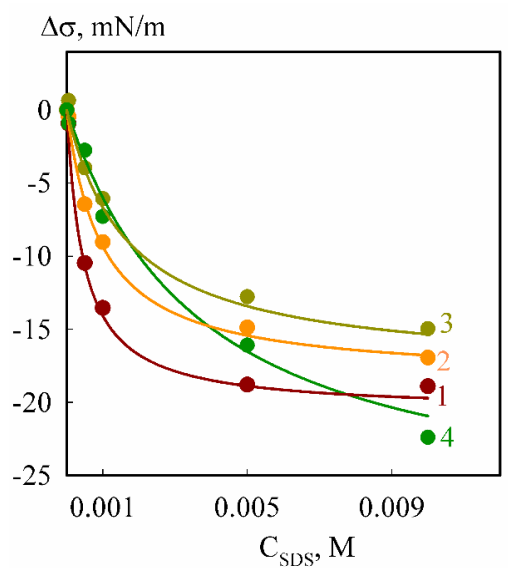

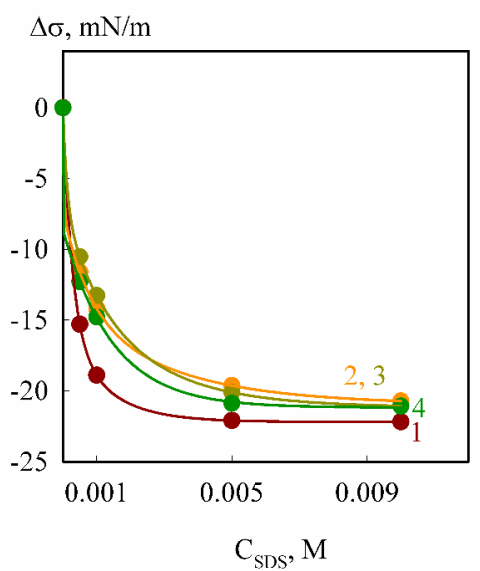

b

Fig. 2. Dependences of surface tension of solutions based on ethaline (a) and reline (b) on the concentration of SDS at different content of water (wt.\%): (1) 0, (2) 10, (3) 50, (4) 80 
Table 1

Critical micelle concentrations of sodium dodecylsulfate in different solvents

\begin{tabular}{c|c}
\hline Solvent & $\mathrm{CMC} \cdot 10^{3}, \mathrm{M}$ \\
\hline water & 8.11 \\
\hline ethylene glycol & 1.35 \\
\hline ethaline & 3.55 \\
\hline ethaline $+10 \% \mathrm{H}_{2} \mathrm{O}$ & 4.17 \\
\hline ethaline $+50 \% \mathrm{H}_{2} \mathrm{O}$ & 4.90 \\
\hline ethaline $+80 \% \mathrm{H}_{2} \mathrm{O}$ & 7.76 \\
\hline reline & 2.14 \\
\hline reline $+10 \% \mathrm{H}_{2} \mathrm{O}$ & 3.47 \\
\hline reline $+50 \% \mathrm{H}_{2} \mathrm{O}$ & 3.63 \\
\hline reline $+80 \% \mathrm{H}_{2} \mathrm{O}$ & 3.47 \\
\hline
\end{tabular}

consequence of the changes in CMC may be due to the corresponding increase in polarity of a medium.

The difference in values of CMC for two DESs under study is evidently caused by the specificity of their chemical composition and intermolecular interactions. Since the micelle formation is accompanied by the partial destruction of intermolecular bonds between the constituents of a solvent, it becomes clear that the molecular structure (i.e. hydrogen bonds) in ethaline-based solutions is partially broken in the course of the micelle formation to a lesser extent than in reline-based systems.

As far as the effect of water content on the CMC is concerned, it should be noted that an increase in $\mathrm{H}_{2} \mathrm{O}$ content in solution based on ethaline results in a growth of $\mathrm{CMC}$, which gradually approaches the value typical of pure water solution (Table 1). In a first approximation, an increase in water concentration in reline-based solution also causes a growth of CMC, although the observed dependence is not monotonic. Probably, these phenomena are due to different impacts of urea and EG on the structure formation and intermolecular interactions in aqueous systems.

To determine the adsorption of SDS at the interface «air/solution», the initial segments of the isotherms of surface tension were treated by graphical differentiation in accordance with the well-known Gibbs equation:

$\Gamma=-\frac{\mathrm{C}}{\mathrm{RT}} \cdot \frac{\mathrm{d} \sigma}{\mathrm{dC}}$,

where $\Gamma$ is the adsorption (surface access), $\sigma$ is the measured surface tension, $\mathrm{C}$ is the molar concentration of a surfactant in the solution, $\mathrm{R}$ is the universal gas constant, and $T$ is the thermodynamic temperature.
The obtained isotherms were further treated using the linearized coordinates of Langmuir equation:

$\frac{\mathrm{C}}{\Gamma}=\frac{1}{\Gamma_{\infty} \mathrm{B}}+\frac{1}{\Gamma_{\infty}} \mathrm{C}$,

where $\Gamma_{\infty}$ is the adsorption corresponding to complete surface coverage, and $\mathrm{B}$ is the equilibrium constant of adsorption.

The plots $C / \Gamma$ vs. $C$ proved to be linear in accordance with Eq. (2) (Fig. 3). This confirms the suitability of the Langmuir model. The calculated adsorption parameters (the equilibrium constants of adsorption and the adsorptions corresponding to complete coverage) are summarized in Table 2. For the sake of comparison, Table 2 also shows the data on the adsorption of SDS in pure water and EG.

Table 2

Parameters of the adsorption of SDS at air/solution interface

\begin{tabular}{l|c|c|c}
\hline \multicolumn{1}{c|}{ Solvent } & $\begin{array}{c}\mathrm{B}, \\
\mathrm{m}^{3} \mathrm{~mol}^{-1}\end{array}$ & $\begin{array}{c}\Gamma_{\infty}, \\
\mathrm{mol} \mathrm{m}^{-2}\end{array}$ & $\begin{array}{c}\Delta \mathrm{G}^{0}{ }_{298}, \\
\mathrm{~J} \mathrm{~mol}^{-1}\end{array}$ \\
\hline water & 51.73 & 5.02 & -36844 \\
\hline ethylene glycol & 0.77 & 1.62 & -23353 \\
\hline ethaline & 5.83 & 3.21 & -25163 \\
\hline ethaline $+10 \% \mathrm{H}_{2} \mathrm{O}$ & 3.65 & 2.69 & - \\
\hline ethaline $+50 \% \mathrm{H}_{2} \mathrm{O}$ & 2.66 & 2.07 & - \\
\hline ethaline $+80 \% \mathrm{H}_{2} \mathrm{O}$ & 4.29 & 1.18 & - \\
\hline reline & 6.38 & 3.94 & -25355 \\
\hline reline $+10 \% \mathrm{H}_{2} \mathrm{O}$ & 3.59 & 2.97 & - \\
\hline reline $+50 \% \mathrm{H}_{2} \mathrm{O}$ & 3.65 & 3.36 & - \\
\hline reline $+80 \% \mathrm{H}_{2} \mathrm{O}$ & 7.49 & 2.91 & - \\
\hline
\end{tabular}

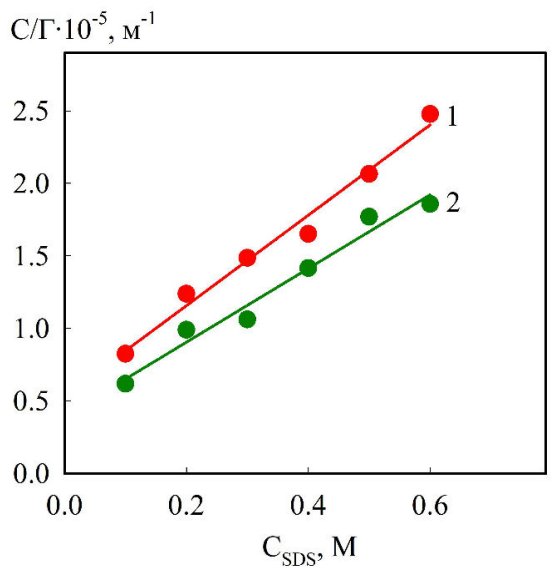

Fig. 3. Isotherms of adsorption of SDS in ethaline (1) and reline (2) plotted in coordinates of Eq. (2) 
Free energy of adsorption $\left(\Delta \mathrm{G}^{0}\right)$ was calculated by the following equation:

$$
\Delta \mathrm{G}^{0}=-\mathrm{RT} \ln (\mathrm{A} \cdot \mathrm{B}),
$$

where $\mathrm{A}$ is the molar concentrations of a «pure» solvent.

Apparently, the value of $\mathrm{A}$ in Eq. (3) is equal to $55.56 \cdot 10^{3} \mathrm{~mol} \mathrm{~m}^{-3}$ and $16.11 \cdot 10^{3} \mathrm{~mol} \mathrm{~m}^{-3}$ for the solutions based on ethylene glycol and water, respectively (they were calculated as the density of the fluid divided by its molecular weight). In order to find A for the DESs under consideration, it should be accepted that one dodecylsulfate anion in the course of adsorption at the interface «air/solution» replaces one molecular associate which consists of 1 molecule of $\mathrm{ChCl}$ and 2 molecules of $\mathrm{EG}$ or 1 molecule of $\mathrm{ChCl}$ and 2 molecules of urea for the cases of ethaline and reline, respectively. The above ratio of the constituents follows from the eutectic composition of the DESs. The appearance of such associates via formation of hydrogen bonds was previously reported in a number of papers [1-3]. Then, one can easily calculate that the value of $\mathrm{A}$ in Eq. (3) is equal to $4.417 \cdot 10^{3} \mathrm{~mol} \mathrm{~m}^{-3}$ and $4.361 \cdot 10^{3} \mathrm{~mol} \mathrm{~m}^{-3}$ for ethaline and reline, respectively.

As follows from the obtained data, the highest value of the equilibrium adsorption constant, (and hence the most negative free energy of adsorption) is observed in the case of adsorption of SDS in water solution, whereas the lowest value is detected for the system based on EG. This is probably due to the corresponding difference in the polarity of the solvents and intensity of hydrophobic interactions in them. The equilibrium constants of adsorption for the DESs-based systems have intermediate values between those observed for water and ethylene glycol solutions. A slightly higher equilibrium constant of adsorption is found for the reline-based system.

The change in the content of water in both ethaline and reline has only a marginal impact on the adsorption equilibrium constant. Even at a relatively high content of $\mathrm{H}_{2} \mathrm{O}(80 \%)$, the values of $\mathrm{B}$ do not approach those typical of pure water (Table 2). To explain the fact that the addition of water has only a slight effect of on the surface activity, one should take into account that the solvophobic sequestration of water molecules occurs in these systems with the formation of nanostructured domains around choline anions [16]. Therefore, the change in water content insignificantly influences the hydrophobic interactions even at a relatively high concentration of $\mathrm{H}_{2} \mathrm{O}$.
It is interesting that the value of the adsorption corresponding to the complete surface coverage $\left(\Gamma_{\infty}\right)$ changes in much the same way as the equilibrium adsorption constant (B) changes. Indeed, according to the decrease of $\mathrm{B}$, the solvents under consideration can be arranged in the following order: water $>$ reline $>$ ethaline $>$ ethylene glycol. It is well known that the Langmuir adsorption concept implies that the value of $\Gamma_{\infty}$ unambiguously specifies both the average surface occupied by an adsorbed molecule (or an ion) in the monolayer and the thickness of the adsorption film at a full surface coverage. Evidently, a comprehensive discussion of the effects of the solvent nature on these parameters of the adsorption layer goes far beyond the topic of this study and there is no sufficient data to characterize exhaustively the observed phenomena. Nevertheless, one can assume that the change in the nature of a solvent causes some changes in spatial orientation of dodecylsulfate anion in a saturated adsorption layer (probably, due to intermolecular interactions).

\section{Conclusions}

This work reported the surface tension and surface activity of sodium dodecylsulfate in solutions based on deep eutectic solvents, ethaline and reline, at the interface «air/solution». It was shown that the values of critical micelle concentration are equal to $3.55 \cdot 10^{-3} \mathrm{M}$ and $2.14 \cdot 10^{-3} \mathrm{M}$ in the solutions based on ethaline and reline, respectively. These values are appreciably lower than that for water solution $\left(8.11 \cdot 10^{-3} \mathrm{M}\right)$.

The equilibrium constants of adsorption of SDS at the interface «air/solution» decrease in the following order: water $>$ reline $>$ ethaline $>$ ethylene glycol. Apparently, the observed dependence is associated with the corresponding changes in the polarity of the solvents and intensity of hydrophobic interactions. The addition of water to the DESs results in an increase in critical micelle concentration and has little effect on the equilibrium constant of adsorption of SDS

\section{Acknowledgments}

This work was financially supported by the Ministry of Education and Science of Ukraine (project no. 0118U003398).

\section{REFERENCES}

1. Smith E.L., Abbott A.P., Ryder K.S. Deep eutectic solvents (DESs) and their applications // Chem. Rev. - 2014. - Vol.114. - P.11060-11082. 
2. Deep eutectic solvents: syntheses, properties and applications / Q. Zhang, K.D.O. Vigier, S. Royer, F. Jerome // Chem. Soc. Rev. - 2012. - Vol.41. - P.7108-7146.

3. Deep eutectic solvents for the production and application of new materials / L.I.N. Tome, V. Baiao, W. da Silva, C.M.A. Brett // Appl. Mater. Today. - 2018. - Vol.10. - P.30-50.

4. The peculiar effect of water on ionic liquids and deep eutectic solvents / Ma C., Laaksonen A., Liu C., Lu X., Ji X. // Chem. Soc. Rev. - 2018. - Vol.47. - P.8685-8720.

5. Formation of type III deep eutectic solvents and effect of water on their intermolecular interactions / Zhekenov T., Toksanbayev N., Kazakbayeva Z., Shah D., Mjalli F.S. // Fluid Phase Equilib. - 2017. - Vol.441. - P.43-48.

6. Shah D., Mjalli F.S. Effect of water on the thermophysical properties of Reline: an experimental and molecular simulation based approach // Phys. Chem. Chem. Phys. - 2014. - Vol.16. - P.23900-23907.

7. Mechanistic study on surface tension of binary and ternary mixtures containing choline chloride, ethylene glycol and water (components of aqueous solutions of a deep eutectic solvent, ethaline) / Y. Rublova, A. Kityk, F. Danilov, V. Protsenko // Z. Phys. Chem. - 2019. - Available from: https://doi.org/10.1515/ zpch-2019-1492.

8. Choline chloride based ionic liquids containing nickel chloride: Physicochemical properties and kinetics of $\mathrm{Ni}(\mathrm{II})$ electroreduction / Kityk A.A., Shaiderov D.A., Vasil'eva E.A., Protsenko V.S., Danilov F.I. // Electrochim. Acta. - 2017. Vol.245. - P.133-145.

9. Effect of water content on physicochemical properties and electrochemical behavior of ionic liquids containing choline chloride, ethylene glycol and hydrated nickel chloride / V.S. Protsenko, A.A. Kityk, D.A. Shaiderov, F.I. Danilov // J. Mol. Liq. - 2015. - Vol.212. - P.716-722.

10. Bobrova L.S., Danilov F.I., Protsenko V.S. Effects of temperature and water content on physicochemical properties of ionic liquids containing $\mathrm{CrCl}_{3} \cdot \mathrm{xH}_{2} \mathrm{O}$ and choline chloride // J. Mol. Liq. - 2016. - Vol.223. - P.48-53.

11. Electrodeposition of chromium coatings from a choline chloride based ionic liquid with the addition of water / Protsenko V.S., Bobrova L.S., Baskevich A.S., Korniy S.A., Danilov F.I. // J. Chem. Technol. Metall. - 2018. - Vol.53. P.906-915.

12. Vykorystann'ya teorii vakansii dl'ya interpretatsii danykh shchodo elektroprovidnosti ionnykh ridyn, yaki mist'yat' khrom(III) khloryd, kholin khloryd i dobavky vody / V.S. Protsenko, L.S. Bobrova, K.S. Burmistrov, F.I. Danilov // Voprosy Khimii i Khimicheskoi Tekhnologii. - 2017. - No. 1.P.27-35.

13. Effect of preliminary electropolishing on corrosion resistance of mild steel in a deep eutectic solvent ethaline / Kityk A.A., Rublova Y.D., Bannyk N.G., Protsenko V.S., Danilov F.I. // Voprosy Khimii i Khimicheskoi Tekhnologii. 2018. - No. 4. - P.14-18.
14. Surfactant behavior of sodium dodecylsulfate in deep eutectic solvent choline chloride/urea / Arnold T., Jackson A.J., Sanchez-Fernandez A., Magnone D., Terry A.E., Edler K.J. // Langmuir. - 2015. - Vol.31. - P.12894-12902.

15. The influence of various factors on corrosion of mild steel in deep eutectic solvents / Rublova Y.D., Kityk A.A., Bannyk N.G., Protsenko V.S., Danilov F.I. // Mater. Today Proc. - 2019. - Vol.6. - P.232-236.

16. Hammond O.S., Bowron D.T., Edler K.J. The effect of water upon deep eutectic solvent nanostructure: an unusual transition from ionic mixture to aqueous solution // Angew. Chem. Int. Ed. - 2017. - Vol.56. - P.9782-9785.

Received 12.09.2019

\section{ПОВЕРХНЕВА АКТИВНІСТЬ НАТРІЙ ДОДЕЦИЛСУЛЬФАТУ НА МЕЖІ ПОДІЛУ ФАЗ «РОЗЧИН НА ОСНОВІ НИЗЬКОТЕМПЕРАТУРНОГО ЕВТЕКТИЧНОГО РОЗЧИННИКА/ПОВІТРЯ»}

\section{С.Д. Рубльова, Н.В. Аміруллоєва, В.С. Проценко, Ф. И. Данилов}

Досліджена поверхнева активність та міцелоутворення натрій додецилсульфату у розчинах на основі низькотемпературних евтектичних розчинників ethaline ma reline (евтектичних сумішей холін хлориду з етиленгліколем та карбамідом, відповідно). Ізотерми поверхневого натягу були оброблені за моделлю Ленгмюра $і$ обчислені адсорбційні параметри на міжфразній межі «розчин/повітря». Показано, що константи адсорбційної рівноваги при зміні природи розчинника зменшуються у наступній послідовності: вода >reline >ethaline >етиленгліколь, що пов'язано зі змінами у полярності цих розчинників та інтенсивності гідрофобної взаємодії. Встановлено, що критичні концентрації міцелоутворення натрій додецилсульфату дорівнюють $3,55 \cdot 10^{-3} \mathrm{M} \mathrm{ma} 2,14 \cdot 10^{-3} \mathrm{M}$ для розчинів на основі ethaline ma reline, відповідно, що нижче, ніж у водному розчині $\left(8,11 \cdot 10^{-3}\right.$ M). Збільшення концентрації добавки води у низькотемпературних евтектичних розчинниках слабко впливає на константу адсорбційної рівноваги та приводить до підвищення величини критичної концентрації міцелоутворення.

Ключові слова: адсорбція, поверхневий натяг, низькотемпературний евтектичний розчинник, натрій додецилсульфат, вплив води. 


\section{SURFACE ACTIVITY OF SODIUM DODECYLSULFATE AT THE INTERFACE «SOLUTION BASED ON A DEEP EUTECTIC SOLVENT/AIR»}

Y.D. Rublova, N.V. Amirulloeva, V.S. Protsenko, F.I. Danilov * Ukrainian State University of Chemical Technology, Dnipro, Ukraine

* e-mail: fdanilov@optima.com.ua

Surface activity of sodium dodecylsulfate and micelle formation in solutions based on deep eutectic solvents ethaline and reline (eutectic mixtures of choline chloride with ethylene glycol and urea, respectively) were investigated. The isotherms of surface tension were treated using Langmuir model and the adsorption parameters at the interface «solution/air» were determined. The change in the nature of a solvent results in a decrease in the adsorption equilibrium constant in the following sequence: water>reline >ethaline >ethylene glycol, which is caused by the corresponding changes in the solvents polarity and intensity of hydrophobic interactions. The critical micelle concentration of sodium dodecylsulfate is equal to $3.55 \cdot 10^{-3} \mathrm{M}$ and $2.14 \cdot 10^{-3} \mathrm{M}$ in solutions based on ethaline and reline, respectively. These values are lower than that in an aqueous medium $\left(8.11 \cdot 10^{-3} \mathrm{M}\right)$. An increase in the content of water additive in deep eutectic solvents has only a marginal impact on the adsorption equilibrium constant, but leads to an increase in the critical micelle concentration.

Keywords: adsorption; surface tension; deep eutectic solvent; sodium dodecylsulfate; effect of water.

\section{REFERENCES}

1. Smith E.L., Abbott A.P., Ryder K.S. Deep eutectic solvents (DESs) and their applications. Chemical Reviews, 2014, vol. 114, pp. 11060-11082.

2. Zhang Q., Vigier K.D.O., Royer S., Jerome F. Deep eutectic solvents: syntheses, properties and applications. Chemical Society Reviews, 2012, vol. 41, pp. 7108-7146.

3. Tome L.I.N., Baiao V., da Silva W., Brett C.M.A. Deep eutectic solvents for the production and application of new materials. Applied Materials Today, 2018, vol. 10, pp. 30-50.

4. Ma C., Laaksonen A., Liu C., Lu X., Ji X. The peculiar effect of water on ionic liquids and deep eutectic solvents. Chemical Society Reviews, 2018, vol. 47, pp. 8685-8720.

5. Zhekenov T., Toksanbayev N., Kazakbayeva Z., Shah D., Mjalli F.S. Formation of type III deep eutectic solvents and effect of water on their intermolecular interactions. Fluid Phase Equilibria, 2017, vol. 441, pp. 43-48.

6. Shah D., Mjalli F.S. Effect of water on the thermophysical properties of reline: an experimental and molecular simulation based approach. Physical Chemistry Chemical Physics, 2014, vol. 16, pp. 23900-23907.

7. Rublova Y., Kityk A., Danilov F., Protsenko V. Mechanistic study on surface tension of binary and ternary mixtures containing choline chloride, ethylene glycol and water (components of aqueous solutions of a deep eutectic solvent, ethaline). Zeitschrift für Physikalische Chemie, 2019. Available from: https://doi.org/10.1515/zpch-2019-1492.
8. Kityk A.A., Shaiderov D.A., Vasil'eva E.A., Protsenko V.S., Danilov F.I. Choline chloride based ionic liquids containing nickel chloride: physicochemical properties and kinetics of $\mathrm{Ni}$ (II) electroreduction. Electrochimica Acta, 2017, vol. 245, pp. 133145.

9. Protsenko V.S., Kityk A.A., Shaiderov D.A., Danilov F.I. Effect of water content on physicochemical properties and electrochemical behavior of ionic liquids containing choline chloride, ethylene glycol and hydrated nickel chloride. Journal of Molecular Liquids, 2015, vol. 212, pp. 716-722.

10. Bobrova L.S., Danilov F.I., Protsenko V.S. Effects of temperature and water content on physicochemical properties of ionic liquids containing $\mathrm{CrCl}_{3} \cdot \mathrm{xH}_{2} \mathrm{O}$ and choline chloride. Journal of Molecular Liquids, 2016, vol. 223, pp. 48-53.

11. Protsenko V.S., Bobrova L.S., Baskevich A.S., Korniy S.A., Danilov F.I. Electrodeposition of chromium coatings from a choline chloride based ionic liquid with the addition of water. Journal of Chemical Technology and Metallurgy, 2018, vol. 53, pp. 906-915.

12. Protsenko V.S., Bobrova L.S., Burmistrov K.S., Danilov F.I. Vykorystann'ya teorii vakansii dl'ya interpretatsii danykh shchodo elektroprovidnosti ionnykh ridyn, yaki mist'yat' khrom(III) khloryd, kholin khloryd i dobavky vody [The application of hole theory for the interpretation of data on conductivity of ionic liquids containing chromium(III) chloride, choline chloride and water additives]. Voprosy Khimii $i$ Khimicheskoi Tekhnologii, 2017, no. 1, pp. 27-35. (in Ukrainian).

13. Kityk A.A., Rublova Y.D., Bannyk N.G., Protsenko V.S., Danilov F.I. Vplyv poperedn'ogo elektropoliruvann'ya na koroziinu stiikist' nyz'kovugletsevoyi stali u nyz'kotemperaturnomu evtektychnomu rozchynnyku ethaline [Effect of preliminary electropolishing on corrosion resistance of mild steel in a deep eutectic solvent ethaline]. Voprosy Khimii $i$ Khimicheskoi Tekhnologii, 2018, no. 4, pp. 14-18. (in Ukrainian).

14. Arnold T., Jackson A.J., Sanchez-Fernandez A., Magnone D., Terry A.E., Edler K.J. Surfactant behavior of sodium dodecylsulfate in deep eutectic solvent choline chloride/urea. Langmuir, 2015, vol. 31, pp. 12894-12902.

15. Rublova Y.D., Kityk A.A., Bannyk N.G., Protsenko V.S., Danilov F.I. The influence of various factors on corrosion of mild steel in deep eutectic solvents. Materials Today: Proceedings, 2019 , vol. 6, pp. 232-236.

16. Hammond O.S., Bowron D.T., Edler K.J. The effect of water upon deep eutectic solvent nanostructure: an unusual transition from ionic mixture to aqueous solution. Angewandte Chemie International Edition, 2017, vol. 56, pp. 9782-9785. 